\title{
The Rio de Janeiro HIV Vaccine Site - I. Recruitment Strategies and Socio-demographic Data of a HIV Negative Homosexual and Bisexual Male Cohort in Rio de Janeiro, Brazil
}

\author{
Frits Sutmoller ${ }^{+}$, Claudia Teresa Vieira de Souza, José Carlos Monteiro, \\ Therezinha Penna
}

Hospital Evandro Chagas, Instituto Oswaldo Cruz, Av. Brasil 4365, 21045-900 Rio de Janeiro, RJ, Brasil

The initial effort of the Brazilian Ministry of Health to be an active partner in the world effort in the preparation of future accurate human immune deficiency virus (HIV) efficacy trials was the establishment of a multi-centered cohort of homosexual and bisexual men. An open cohort was established to determine the HIV incidence and the socio-behavioral aspects involved in Rio de Janeiro. A total of 318 potential participants, originated from multiple sources (health units, public information, snowball recruitment), were screened and recruitment became effective through the direct involvement of target communities (with the support of Non Governmental Organizations) and the population. Among this group, seropositivity for sexually transmitted diseases was high with 23, 32 and $46 \%$ for HIV, syphilis and hepatitis B, respectively. The socio-demographic data from the first 200 participants of this HIV negative cohort suggests that the cohort volunteers are an appropriate sample of the general male population of the State of Rio de Janeiro.

Key words: human imunodeficiency virus - syphilis - hepatitis B - homosexual - bisexual - male - prevalence cohort - socio-demographic aspects

In 1992, Brazil was selected by the World Health Organization, through its Global Programme on AIDS (GPA/AIDS), as one of four countries, along with Thailand, Uganda and Rwanda, to receive technical and financial support to prepare for future human immune deficiency virus (HIV) vaccine efficacy (Phase III) trials. A multi-centered study group located in three states (Rio de Janeiro, Minas Gerais and São Paulo) was established with the purpose of obtaining accurate estimate of HIV incidence necessary for vaccine trial sample size determination. The Brazilian Ministry of Health, together with the government of the three states decided to give priority to an open cohort of homosexual and bisexual men as they supposed that high incidence rates would be found in these groups and that the relation with social and behavioral aspects needed to be investigated.

Financial support was provided by the National STD/ AIDS Program of the Brazilian Ministry of Health, the Global Programme on AIDS/WHO, Conselho Nacional de Pesquisa (CNPq) and the PAPES Program of the FIOCRUZ.

${ }^{+}$Corresponding author. Fax: +55-21-260.9749

Received 16 May 1996

Accepted 4 September1996
The potential study populations, epidemiological methods, and the ethical consideration have been previously described (Heyward et al. 1994, Greco 1994, Sutmoller et al. 1994, 1996). The State of Rio de Janeiro had a cummulative number of reported AIDS cases, to the end of 1995, of 11,433 with a cumulative coefficient index of 89 per 100,000 inhabitants in the State (Ministério da Saúde 1995).

In this paper we will discuss recruitment strategies and socio-demographic data obtained from the first 200 cohort volunteers considered pertinent to the establishment of a long term (three years) open cohort among a HIV negative homosexual and bisexual men. We also report on findings about sexually transmitted diseases (STD) seroprevalence in the potential study participants as it reflects risk behavior for HIV infection. This report covers the period of January 1995 to April 1996.

\section{MATERIALS AND METHODS}

This study was approved by the Oswaldo Cruz Research Ethics Committee and volunteers were admitted after signing an informed consent form.

Located on the campus of the Oswaldo Cruz Foundation, the Evandro Chagas Hospital (HEC) was selected as the main site for the study because of its high reputation in bio-medical research. A 
specific area was assigned in order to offer an adequate environment for this type of investigation (e.g. privacy and volunteer comfort). A limited number of volunteers was interviewed at the Servidores do Estado Hospital (HSE) of Rio de Janeiro in downtown and at the Sexually Transmitted Diseases Clinic, Fluminense Federal University (STD/UFF), located in Niterói, State of Rio de Janeiro, with the aim of decentralizing study activities.

The State of Rio de Janeiro has a population of 12.8 million inhabitants with a male population of 6.2 million. The male urban population is 5.8 million, $78.4 \%$ of which (4.9 million) live in the Metropolitan area where this study was conducted (FIBGE 1991).

Study population - Homosexual or bisexual men, ranging in age from 18 to 50 years, who live in the State of Rio de Janeiro.

Cohort entry criteria - Similar to the study population but with a recent $(<1$ month) HIV negative test.

Recruitment - Volunteers were recruited from (1) Municipal Health Centers: three health units Centro Municipal de Saúde (CMS) Oswaldo Cruz, CMS João Barros Barreto, Posto de Assistência Médica (PAM) 13 de Maio - were initially selected according to their location, concentration of free public HIV testing and the centralization of outpatient treatment for HIV positive patients. Since then HIV testing has changed and is now done in Anonymous Testing Centers and health units, requiring new alternative approaches which are being implemented; (2) Public Information - Information to the public about STD/AIDS Prevention Project consisted of a combination of media coverage (interviews with staff members in newspapers, radio, and television) and production, and distribution of pamphlets. Paid advertisements were printed during two months (early 1995), in newspapers close to the sex related activities classified section ( $O$ Globo, O Dia and Jornal do Brasil). A community radio in Nova Iguaçu aired information and announcements about the Project during a two month period (March and April 1996); (3) Community activities - Active information was disseminated at the homosexual night clubs and bars by staff-related personnel with the direct participation of "grass root" non governmental organizations (NGOs) - primarily the "Movimento de Emancipação Homossexual" (ATOBÁ) and the "Grupo 28 de Junho". Field work, carried out by qualified recruiters, with groups of male prostitutes and transvesties, was also a source of volunteers which started in 1996; (4) Volunteers The recruiting activities performed by the volunteers proved to be effective with an cumulative effect (also called "snowball" or "net working" recruitment) and were accelerated, from October 1995, by the establishment of an expense reimbursement for specially trained volunteers, working as recruiters.

Study procedures - Potential volunteers were seen by the study staff and received detailed information about the study objectives and procedures; they also received pre-test counseling and an explanation of what was expected of a volunteer. A study entry form was then completed together with both a questionnaire to provide information on opinions and attitudes about health and HIV and psychological tests pertinent to sexual risk behavior. A blood specimen was drawn (for HIV, syphilis and hepatitis B markers and for a complete blood count) and sent to the laboratory under confidential specifications.

Candidates returned aproximately one week later for the laboratory results. All candidates, independent of HIV status, received post-test counseling. Those with a positive HIV serology were referred to a health unit near their residence or were included in the HEC clinical investigations of the asymptomatic HIV positive cohort if they fitted the entry criteria. Those with a negative HIV serology were invited to participate in the Program and after final discussions were asked to sign the informed consent form.

The admission questionnaire provided identification, address and procedures for future contact; it is a confidential document accessible only to investigators. Upon admission to the cohort the volunteer received a six digit number which identified him in all other study forms. A social and behavioral questionnaire composed of 100 question items was then administered by one of the study psychologists. A medical examination was part of the admission procedures.

Data collection - The study team which was previously trained to obtain standardized answers was in charge of data collection. The data referred to in this study was obtained from (1) initial visit form - Reasons for coming to the study, referral to the study, previous knowledge about the project, previous serology test results; (2) psychological profile - Health locus of control, interpersonal sensitivity (SCL-90) and impulse control (NEO Personality Profile) combined with other knowledge, attitude, beliefs and practices (KABP) questions. The psychological profile is a supplementary study and investigated exclusively at the Rio de Janeiro cohort site; (3) social behavioral questionnaire Includes social and demographic data (age, marital status, living conditions, employment status, salary and number of people living on the family salary, religion), HIV/AIDS knowledge, sexual 
attitudes and present sexual practices as well as the volunteer's beliefs on health and AIDS-related subjects. This will be discussed in detail in a separate paper.

Laboratory exams - Venous blood was collected for viral serology obtained via serum Vacutainer tubes $(10 \mathrm{ml})$ and a specimen was obtained for a complete blood count with an EDTA Vacutainer $(5 \mathrm{ml})$ tube. The laboratory tests were done by the Clinical Laboratory (Head Immunology Laboratory: Ingebourg Georg) of he HEC and the hepatitis test by the Virology Department (Head: Dr Clara Yoshida).

The HIV test was done with two different enzyme linked immunoassay (ELISA) HIV UniformForm II (Organon Teknika, Boxtel, The Netherlands) and Enzygnost anti-HIV 1/2 Plus (Behring, Marburg, Germany). All specimens were tested by indirect immunoflourescence (IF) produced by Bio-Manguinhos (Department of Technological Development of FIOCRUZ).

Syphilis serology was done for the Treponema pallidum by the Venereal Disease Research Laboratory (VDRL) method and the haemaglutination absorption (TPHA) test (Randox Laboratories, Antrim, U.K.).

Hepatitis markers were done using in-house enzyme immunoassays (Bio-Manguinhos FIOCRUZ) with controlled specificity and sensi- tivity according to available commercial kits: HBsAg, anti-HBs and anti-HBc. No confirmation test for HBsAg was done.

Complete blood count was performed according to the standard procedures.

Data analysis - A data set was developed for the purpose of data analysis in FoxPro (version 2.0) and evaluated (frequency tables and Chi-square test for p-value calculations) with EPIINFO (version 5.0).

\section{RESULTS}

Recruitment - Sources of potential cohort volunteers (Table I) changed as recruitment efforts varied during the study. One of the study objectives was to determine which recruiting method should be used with this population. During 1994 most efforts and financial commitment were concentrated on the health sector (health units, hospitals, private physicians, etc.); they produced $45 \%$ of the first 56 candidates. Collaboration with the NGOs was still limited and the study pamphlet distribution only started in the last trimester of 1994 making the recruitment initially slow and more difficult than originally anticipated. During the first trimester of 1995, NGOs efforts increased with an active pamphlet dissemination. The efficacy of both newspaper paid announcements and of media coverage was evaluated. These actions were

\section{TABLE I}

Recruitment sources of homo- and bisexual men for a HIV negative cohort per trimester (1994 through April 1996)

\begin{tabular}{|c|c|c|c|c|c|}
\hline Trimester & $\begin{array}{l}\text { Health } \\
\text { units }\end{array}$ & $\begin{array}{c}\text { Public } \\
\text { information }\end{array}$ & Community & Volunteer & Total \\
\hline \multicolumn{6}{|l|}{1994} \\
\hline Jan./Mar. & 1 & - & 1 & 1 & 3 \\
\hline Apr./Jun. & 4 & - & 2 & 2 & 8 \\
\hline Jul./Sep. & 12 & - & 3 & 10 & 25 \\
\hline Oct./Dec. & 8 & 4 & 5 & 3 & 20 \\
\hline Total & 25 & 4 & 11 & 16 & 56 \\
\hline$\%$ & 45 & 7 & 20 & 29 & \\
\hline \multicolumn{6}{|l|}{1995} \\
\hline Jan./Mar. & 13 & 12 & 11 & 4 & 40 \\
\hline Apr./Jun. & 2 & 6 & 9 & 6 & 23 \\
\hline Jul./Sep. & 3 & 0 & 4 & 13 & 20 \\
\hline Oct./Dec. & 1 & 0 & 28 & 39 & 68 \\
\hline Total & 19 & 18 & 52 & 62 & 151 \\
\hline$\%$ & 13 & 12 & 34 & 41 & \\
\hline \multicolumn{6}{|l|}{1996} \\
\hline Jan./Mar. & 3 & 1 & 23 & 37 & 64 \\
\hline Apr. & 2 & 1 & 12 & 18 & 33 \\
\hline Total & 5 & 2 & 35 & 55 & 97 \\
\hline$\%$ & 7 & 2 & 36 & 57 & \\
\hline Total & 49 & 24 & 98 & 133 & 304 \\
\hline$\%$ & 16 & 8 & 32 & 44 & \\
\hline
\end{tabular}


important for community information but poor for volunteer recruitment. During the second and third trimester of 1995, due to lack of continued financial support, recruitment activities were reduced and subsequently the number of people coming to the unit diminished. With renewed support we were able to stimulate volunteer snowball and NGO based recruitment. In the last trimester of 1995 and early 1996, over $90 \%$ of the recruitment came from the NGOs and volunteers.

For the first 318 volunteers, the main motivation to participate in the study was to have a reliable HIV test, rapid test results, access to free condoms and the wish to help in a study related to AIDS prevention.

Seroprevalence data - Three STD infections HIV, syphilis and hepatitis B - were monitored serologically at the initial visit (Table II). The overall HIV seropositivity was $23.6 \%$. Syphilis positive serology accounted for $32.8 \%$ of potential study participants and evidence of hepatitis B infection was shown in $47.9 \%$ of men. The first trimester of 1996 showed an increase of seropositivity due to the recruitment of commercial sexual workers ("michês").

The seroprevalence of syphilis and hepatitis B was significantly different among the potential study participants depending on HIV status. HIV carriers were positive for syphilis (47.7\%), hepatitis B markers (79.7\%), and HBsAg (9.1\%). The HIV negative have shown results of $27.5 \%, 36.7 \%$ and $3.7 \%$, respectively. Both groups have higher prevalence of these infections than the general population.

Social and demographic data - The age distribution of the first 200 volunteers enrolled in the cohort study (Table III) is similar to the male 1850 year male population in the State of Rio de

TABLE II

Seroprevalence of sexually transmitted diseases during the recruitment visit for a homo- and bisexual HIV negative cohort study (1994-1996)

\begin{tabular}{|c|c|c|c|c|c|c|}
\hline \multirow[t]{2}{*}{ Trimester } & \multicolumn{2}{|c|}{$\begin{array}{c}\text { HIV (+) } \\
n=318\end{array}$} & \multicolumn{2}{|c|}{$\begin{array}{c}\text { Syphilis (+) } \\
\mathrm{n}=271\end{array}$} & \multicolumn{2}{|c|}{$\begin{array}{c}\text { Hepatitis B } \\
n=234\end{array}$} \\
\hline & $\#$ & (\% pos) & \# & (\% pos) & $\#$ & (\% pos) \\
\hline \multicolumn{7}{|l|}{1994} \\
\hline Jan./Mar. & 1 & 33.3 & 1 & 100 & 0 & - \\
\hline Apr./Jun. & 3 & 42.9 & 0 & - & 2 & 100 \\
\hline Jul./Sep. & 4 & 15.4 & 1 & 8.3 & 7 & 63.6 \\
\hline Oct./Dec. & 5 & 26.3 & 4 & 25.0 & 7 & 46.6 \\
\hline Total & 12 & 22.2 & 5 & 23.1 & 16 & 57.1 \\
\hline \multicolumn{7}{|l|}{1995} \\
\hline Jan./Mar. & 8 & 20.5 & 6 & 222 & 11 & 40.7 \\
\hline Apr./Jun. & 5 & 20.0 & 5 & 20.8 & 12 & 54.5 \\
\hline Jul./Sep. & 1 & 4.8 & 7 & 41.2 & 6 & 42.9 \\
\hline Oct./Dec. & 17 & 23.6 & 27 & 39.1 & 27 & 44.3 \\
\hline Total & 31 & 19.7 & 44 & 32.4 & 56 & 45.2 \\
\hline \multicolumn{7}{|l|}{1996} \\
\hline Jan./Mar. & 20 & 32.2 & 28 & 46.7 & 28 & 49.1 \\
\hline Apr. & 11 & 25.0 & 12 & 27.9 & 12 & 48.0 \\
\hline Total & 31 & & 40 & & 40 & \\
\hline Total & 75 & 23.6 & 91 & 33.5 & 112 & 47.9 \\
\hline
\end{tabular}

TABLE III

Seroprevalence of syphilis and hepatitis B at time of recruitment for the HIV negative cohort study according to HIV serological status (1994-1996)

\begin{tabular}{|c|c|c|c|c|c|c|}
\hline \multirow[b]{2}{*}{ Serological status } & \multicolumn{2}{|c|}{$\begin{array}{c}\text { Syphilis } \\
n=291\end{array}$} & \multicolumn{2}{|c|}{$\begin{array}{c}\text { Hepatitis B } \\
n=255\end{array}$} & \multicolumn{2}{|c|}{$\begin{array}{c}\text { HBsAg } \\
n=245\end{array}$} \\
\hline & \# & $\%$ & \# & $\%$ & $\#$ & $\%$ \\
\hline HIV (+) & 26 & 47.2 & 47 & 79.7 & 5 & 9.1 \\
\hline HIV ( -) & 65 & 27.5 & 72 & 36.7 & 7 & 3.7 \\
\hline p-value & $<.001$ & & $<.001$ & & 0.1 & \\
\hline
\end{tabular}

Chi-Square 
Janeiro, except for the 20-24 age group, which in our study represented $40 \%$ of the volunteers. The ethnic distribution, cited by the volunteer is white $53 \%$, mulato $28.5 \%$ and negro $9 \%$.

The marital status information (Table IV) revealed that $83 \%$ were single and $12 \%$ married or separated. Twelve percent of the study participants had children. Half lived with their parents, 23\% lived alone, $20.5 \%$ lived with either a friend or companion and $2 \%$ lived with their wives. Half of the volunteers claimed to have a religion, most frequently "spiritual" and catholic faiths, and a smaller percentage had the "candomblé" and protestants faiths.

The educational level of the participants showed that $31.5 \%$ had incomplete primary education, $40 \%$ had complete secondary education and $20 \%$ had university education. Employment status revealed that $70.5 \%$ were working at the time of the interview and $46 \%$ earned as from one to six minimum salaries (MS) $(1 \mathrm{MS}=\mathrm{R} \$ 100,00=\mathrm{US} \$ 105.00$ at the time of the study period).

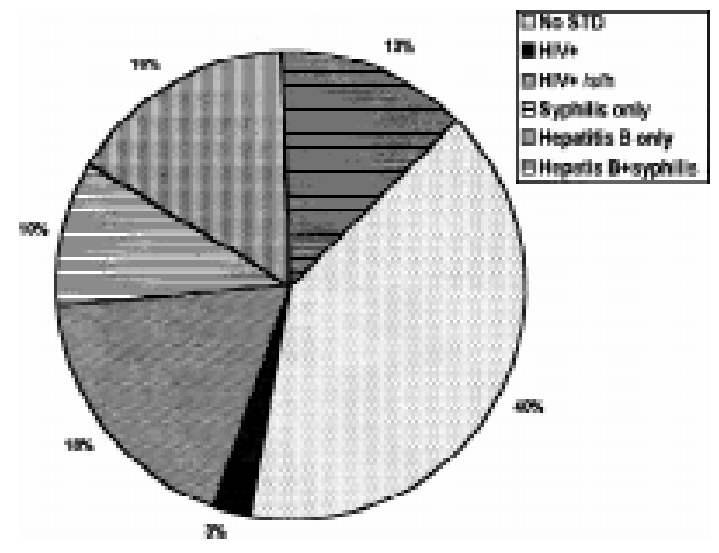

Sexually transmitted diseases prevalence among the candidates for the HIV negative cohort

No STD: no sexually transmitted diseases

HIV+: HIV positive, yet negative for syphylis and hepatitis B $\mathrm{HIV}+/ \mathrm{S} / \mathrm{H}$ : HIV positive and also positive for both or either syphilis and hepatitis B

\section{TABLE IV}

Age, income distribution and educational level of the cohort participants and comparison with the State of Rio de Janeiro 1991 census

\begin{tabular}{|c|c|c|c|c|}
\hline & \multicolumn{2}{|c|}{ Cohort volunteers } & \multicolumn{2}{|c|}{$\mathrm{IBGE}^{a}$} \\
\hline & Number & Percentage & Number & Percentage \\
\hline & \multicolumn{2}{|l|}{$\mathrm{n}=200$} & 2929449 & \\
\hline \multicolumn{5}{|l|}{ Age (years): } \\
\hline $18-19$ & 14 & 7.0 & 216880 & 7.4 \\
\hline $20-24$ & 80 & 40.0 & 532460 & 18.2 \\
\hline $25-29$ & 37 & 18.5 & 532048 & 18.2 \\
\hline $30-34$ & 33 & 16.5 & 498277 & 17.0 \\
\hline $35-39$ & 20 & 10.0 & 437874 & 14.9 \\
\hline $40-44$ & 12 & 6.0 & 371687 & 12.7 \\
\hline $45-49$ & 4 & 2.0 & 286433 & 9.8 \\
\hline 50 & 0 & & 53790 & 1.8 \\
\hline \multicolumn{5}{|l|}{ Volunteers' income } \\
\hline No income & 19 & 9.5 & 59720 & 3.7 \\
\hline$<1 \mathrm{MS}^{b}$ & 5 & 2.5 & 26948 & 16.5 \\
\hline $1-3$ & 80 & 40.0 & 678673 & 42.0 \\
\hline $3-6$ & 38 & 16.0 & 263401 & 16.4 \\
\hline $6-10$ & 18 & 9.0 & 179958 & 11.2 \\
\hline $10-14$ & 5 & 2.5 & 76917 & 4.8 \\
\hline+14 & 12 & 6.0 & 85943 & 5.4 \\
\hline Unknown & 5 & 2.5 & - & - \\
\hline \multicolumn{5}{|l|}{ Educational level } \\
\hline Illiterate & 1 & 0.5 & 166677 & 16.6 \\
\hline Primary - incomplete & 62 & 31.0 & 325555 & 32.4 \\
\hline - complete & 40 & 20.0 & 204421 & 20.3 \\
\hline Secondary level & 50 & 25.0 & 212636 & 21.2 \\
\hline University level & 42 & 21.0 & 95820 & 9.5 \\
\hline Unknown & 5 & 2.5 & - & - \\
\hline
\end{tabular}

$a$ : FIGBE $1991 ; b$ : minimum salary $=\mathrm{R} \$ 100,00=\mathrm{US} \$ 105.00$ 
TABLE V

Socio-demographic variables of the first 200 participants of a homo- and bisexual HIV negative cohort (1994-1996)

\begin{tabular}{llrr}
\hline & & Number & \multicolumn{1}{c}{$\%$} \\
\hline Marital status & single & 168 & 84.0 \\
& separated or married & 23 & 11.5 \\
& other & 9 & 4.5 \\
Children & & & \\
& no & 165 & 82.5 \\
& yes n=27 & 29 & 14.5 \\
& unknown & 6 & 3.0 \\
Living with & parents & 100 & 50.0 \\
& alone & 46 & 23.0 \\
& friend/companion & 41 & 20.5 \\
& wife/children & 4 & 2.0 \\
& others & 9 & 4.5 \\
& & & \\
Employment & active & 141 & 70.5 \\
& unemployed & 46 & 23.0 \\
& student & 7 & 3.5 \\
& unknown & 6 & 3.0 \\
& & & \\
Ethnic group & white & 107 & 53.5 \\
& mulato & 59 & 28.5 \\
& negro & 18 & 9.0 \\
& indian & 3 & 1.5 \\
& yellow & 2 & 1.0 \\
& unknown & 7 & 3.5 \\
\hline & & &
\end{tabular}

\section{DISCUSSION}

Brazil was selected by the World Health Organization (now coordinated by UNAIDS) as one of the four developing countries which could be prepared for future Phase III HIV vaccine (efficacy) trials. The country was chosen for its supposedly high incidence in AIDS [fourth in world ranking (WHO 1994), totalling 76,396 reported cases up to the end of 1995 (Ministério da Saúde 1995)] and for the availability of laboratory facilities, combined with technical expertise. Political willingness and continued financial support have made it feasible for Brazil to develop this multicentered preparedness and the capacity to participate in future efficacy trials, on the advent of a future experimental vaccine.

The decision to investigate HIV incidence in Brazil by studying a cohort of homo- and bisexual men has proven to be adequate in Rio de Janeiro due to the high STD prevalence encountered in our study population. Also the social organization of "grass root" NGOs made access to this population group feasible and is effective in mobilizing their peers. Morever, the absolute number of AIDS cases in men who practice sex with other men, notified to the Brazilian Ministry of Health, continues to grow (Bastos et al. 1995).

Recruitment strategies for homosexual cohort studies in Brazil are limited and includes a study performed in Rio de Janeiro (Parker 1994). The summary of recruitment strategies in the present study includes: (1) direct information - Although dissemination among target populations (bars, gay territories, etc.) has low recruitment efficacy it ensures awareness of the Project's existence and availablity; (2) health units - Due to multiple problems encountered in the public system in Rio de Janeiro their contribution was poor; (3) NGOs involvement - Was crucial to the success and became apparent through the continuous and bilateral support between the NGOs and the Project. This was possible after the credibility and seriousness of the Project was established; (4) snowball recruitment - Has proven to be very effective and is now the main source of volunteers. Availability of "on demand" counselling and group activities have contributed to the volunteer's personal involvement.

The STD disease prevalence in our study population was high. As one third of the volunteers in our cohort stated that they continue to practice unsafe sex, the incidence of the disease in this group can be expected to remain high, during the remainder of the cohort study.

The 23\% HIV prevalence in this homosexual population compares to the $22 \%$ found at an STD clinic in Rio de Janeiro (Oscar Berro, personal communication). By comparison the prevalence in blood donors was $0.4 \%$ in Rio de Janeiro (Vanderborght et al. 1993) and 0.28\% in southern Brazil (Vasconcelos et al. 1994). In other homosexual populations similar prevalence rates have been found (Morales et al. 1994) and even higher rates were found in North Carolina (Schoenbach et al. 1993), a state wthin the United States with low overall STD incidence. Our prevalence was higher than those found in San Francisco, within the United States (Lemp et al. 1994), Amsterdam in The Netherlands (Keet et al. 1993) and Tijuana, Mexico (Güerenã-Burgueño et al. 1991) where the rates, in similar populations, were 9,5 and $12 \%$, respectively.

In our study one third of the volunteers showed evidence of contact with syphilis. This data compares to blood donors studies $(0.86 \%)$ in Rio de Janeiro (Vanderborght et al. 1993) and in southern Brazil (0.28\%) (Vasconcelos et al. 1994). In a study with AIDS patients in São Paulo (Gir et al. 1994) the rate was similar (30\%).

The hepatitis B antibody and/or HBsAg carrier rate in our study was high $(46 \%)$ and rates found at blood donation centers were less than $20 \%$ 
(Clara Yoshida, personal communications). The HBsAg rate (3.7 in HIV negative and 9.1 in HIV positive volunteers) was also higher than that found among blood donors in Rio de Janeiro (Vanderborght et al. 1993) and southern Brazil (Vasconcelos et al. 1994) where rates were 1.6 and 0.78 , respectively. In a study with patients with AIDS from São Paulo (Gir et al. 1994) this rate was 33\% and in Europe (Lemp et al. 1994) the rate was $20 \%$. Our $80 \%$ positivity rate was similar to that found in Italy where anti-HBc in HIV (+) was 77\% (Francisci et al. 1995).

Although this study is being carried on in a city where the overall prevalence in the general population of HIV and STD seems to be relatively low, the prevalence among the homosexual population remains high. This indicates that a high incidence can be expected among the subjects of our ongoing cohort.

Lessons learned from the syphilis epidemic should be an important guide in our response to the present HIV epidemic (Cutler \& Arnold 1988). Efforts at individual and public training, frequent serological testing, scientific information programs, prevention methods (condom distribution) and goverment subsidised treatment for infected patients made difference even when effective treatments were not available. Another important byproduct of this study refers to hepatitis B infection. If the results of our investigation are confirmed by the other centers participating in this multicentered study, this would provide support for public health authorities for enhancing preventive vaccination efforts and control strategies for hepatitis B infection. This has also been suggested by Meheus et al. (1995).

The socio-demographic information from the first 200 volunteers in the HIV negative cohort is relevant to determine which type of population might be available for efficacy trials. In this study, the lower income population seems to be the most motivated group and the most willing to participate. The average age of the men recruited for the HIV negative cohort was lower than the male 1850 year male population of the State of Rio de Janeiro. This is a relevant finding on the grounds that this is the age of expected higher risk due to the involvement in sexual experimentation.

The educational level reported in this study (46\% of the volunteers have completed secondary education) is slightly higher than that reported for the general public (FIBGE 1991) where $31 \%$ of the urban males, between the ages of 20-49, completed secondary education. In one of our previous reports (Souza 1996) this rate was $49.1 \%$ and in a similar study performed in Rio de Janeiro (Parker et al. 1995) this rate was $86.4 \%$. This sug- gests that our investigation reflects a recruitment of men whose educational level is more compatible with that of the local population. Whenever evaluating recruitment techniques it is important to be aware of some selection bias that could jeopordise the study, by making it not representative of the general public.

The results obtained in Rio de Janeiro in the Brazilian multi-centered study offered evidence that the recruitment of a large number of volunteers is feasible, both when multiple recruitment sources are used and there is direct involvement of the target population and the general public. The STD prevalence findings suggest that high incidence rates will be found in this community, making it feasible for Rio de Janeiro to be an effective partner of the Brazilian Ministry of Health's efforts to prepare for future HIV vaccine efficacy trials.

\section{ACKNOWLEDGMENTS}

To the volunteers and NGO leadership which have understood the social importance of participating in this scientific effort, withstanding dificulties due to social and cultural pressures. To support provided by the Hospital Evandro Chagas Clinical Laboratory and the National Reference Center of Viral Hepatitis that made it possible to execute this study. To our staff members: Amilton Xavier Jr, Paulo Starling, Helena Santos, Dionne Peluso, Maria José Maia da Silva and Nelly Medeiros da Cruz. To Dr Carlos Serapião and Ms Therezinha Piemtzaeur for reviewing the manuscript.

\section{REFERENCES}

Bastos FI, Szwarcwald CL, Castilho EA 1995. Epidemia de AIDS em São Paulo: Subsídios da análise espacial. Bol Epidemiol AIDS 7: 5.

Cutler JC, Arnold AC 1988. Veneral Disease Control by Health Departments in the Past: Lesson for the Present. Am J Publ Health 78: 372-376.

Francisci D, Baldelli F, Papili R, Stagni G, Pauluzzi S 1995. Prevalence of HBV, HDV and HCV hepatitis markers in HIV positive patients. Eur J Epidemiol 11: 123-126.

FIBGE - Fundação Instituto Brasileiro de Geografia e Estatística 1991. Censo Demográfico 1991: resultados do universo relativo às variáveis da população e dos domicílios. Rio de Janeiro $I B G E$ 20: 262-281.

Gir E, Duarte G, Martinez R, Moriya TM, Figueredo JF, da Costa JC 1994. Expressão epidemiológica de outras doenças sexualmente transmissíveis entre pacientes de AIDS. Rev Saú Púb 28: 93-99.

Greco D 1994. Aspectos éticos dos ensaios clínicos com vacinas anti-HIV/AIDS no Brasil. In PNDST/AIDS/ MS. Cadernos técnicos 1: 16-21.

Güerenã-Burgueño F, Benenson AS, Sepúlveda-Amor J 1991. HIV-1 prevalence in selected Tijuana subpopulations. Am J Publ Health 81: 623-625.

Heyward WL, Osmanov S, Saba J, Esparza J, Belsey E, Stoneburner R, Kaldor J, Smith PG 1994. Preparation for Phase III HIV vaccine efficacy trails: meth- 
ods for the determination of HIV incidence. AIDS 8: 1285-1291.

Keet IP, van der Bergh HS, van Griensven GJ, Coutinho RA, Sandfort TG, van der Hoek JA 1993. HIV infectie en riskant sexueel gedrag onder jonge homoseksuele mannen te Amsterdam, 1992. Ned Tijdschr Geneeskd 137: 2709-2712.

Lemp GF, Hirozawa AM, Givertz D, Nieri GN, Anderson L, Lindegren ML, Janssen RS, Katz M 1994. Seroprevalence of HIV and risk factors among young homosexual and bisexual men: The San Francisco / Berkeley Young Men's Survey. JAMA 272: 449459.

Meheus A 1995. Risk of hepatitis B in adolescence and young adulthood. Vaccine 13 (Suppl. 1): S31-34.

Ministério da Saúde 1995. Boletim Epidemiológico de AIDS 8: 18.

Morales MA, Pineda JA, Leal M, Pino R, Torronteras R, Sanchez Quijano A, Lissen E 1994. Prevalencia de anticuerpos frente al virus de la hepatitis C en um coletivo de varones homosexuales. Med Clin Barc 102: 478-479.

Parker R 1994. Sexo entre homens: consciência de AIDS e comportamento sexual entre homens homossexuais e bissexuais no Brasil, p.129-149. In R Parker, C Bastos, J Galvão, JS Pedrosa (eds). A AIDS no Brasil. Rio de Janeiro, Relume Dumará, ABIA. IMS/ UERJ.

Parker R, Mota MPda, Guimarães K, Terto Jr V 1995. Práticas sexuais e conscientização sobre AIDS: uma pesquisa sobre o comportamento homossexual $e$ bissexual. Rio de Janeiro, ABIA: IMS, UERJ, mimeo. $160 \mathrm{pp}$.

Schoenbach VJ, Landis SE, Weber DJ, Mittal M, Koch GG, Levine PH 1993. HIV seroprevalence in sexually transmitted disease of clients in a low prevalence southern state. Evidence of endemic sexual transmission. Ann Epidemiol 3: 281-288.

Souza CTV 1996. Subsídio ao estudo de incidência do Vírus da Imunodeficiência Humana entre homens com práticas homossexuais e bissexuais no Rio de Janeiro. MSc Thesis, Escola Nacional de Saúde Pública /FIOCRUZ, Rio de Janeiro, 85 pp.

Sutmoller F, Morgado M, Bongertz V 1996. Por que o Brasil testa vacina anti-HIV? Ciência Hoje 20: 62 64.

Sutmoller F, Souza CTV, Penna T, Starling P, Martins H, Costa D, Silva MJ, Santos A, Silva G, Monteiro JC 1994. Aspectos críticos na condução de ensaios clínicos de vacinas na fase I/II no Brasil. Programa Nacional de DST/AIDS, Ministério da Saúde. Cadernos Técnicos 1: 22-26.

Vanderborgt BOM, Reis AMM, Rouzere CD, Salgado da Silva R, Yoshida CFT, Franco LGP, Maertens G, Van Heuverswijn H, Moreira Pereira J 1993. Prevalence of anti-hepatitis $\mathrm{C}$ virus in the blood donor population of Rio de Janeiro. Vox Sang 65: 122125.

Vasconcelos HCFF, Yoshida CFT, Vanderborght BOM, Schatzmayr HG 1994. Hepatitis B and C prevalences among blood donors in the South Region of Brazil. Mem Inst Oswaldo Cruz 89: 503-507.

WHO - World Health Organization 1994. Images of the epidemic. Geneva. 122 pp. 